\title{
INFLUENCE OF WATER HYACINTH ON VERTICAL VELOCITY PROFILE AND DRAG COEFFICIENT IN IRRIGATION CANALS
}

\author{
Alaa-Eldin M. Abd-Elaal ${ }^{a^{*}}$, Adel A.Mahmoud ${ }^{a}$, Hassan I. Mohamed \\ ${ }^{a}$ Civil Engineering Department, Faculty of Engineering, Sohag University, Egypt \\ ${ }^{b}$ Civil Engineering Department, Faculty of Engineering, Assiut University, Egypt \\ *Corresponding author. Email: Dralaa.m.Abd.Elaal@gmail.com
}

\begin{abstract}
The presence of aquatic vegetation in irrigation canals retards water flow through additional drag force. The aim of present study is to investigate the impact of water hyacinth on vertical velocity profile and drag coefficient in irrigation canals. To achieve this aim experimental program was carried out in a circulating water flume, using water hyacinth. Four different vegetation densities, three different vegetation root depths and three different vegetation zone lengths were used with smooth and rough channel bed. The case without water hyacinth was considered as comparative case. It was found that, for the case without water hyacinth, vertical velocity profile was resembled for theoretical logarithmic distribution in open channel. For the case with water hyacinth velocity vertical profiles became close to the theoretical velocity distribution in a closed conduit but did not reach zero at water surface. Also vegetation density, vegetation root depth, vegetation zone length and bed roughness have a significant effect on the position of maximum velocity. Also the vegetation drag force increases by increasing vegetation density, vegetation root depth and vegetation zone length. In addition, equations were deduced using multiple linear regression analysis to calculate vegetation drag force for both smooth and rough flume bed.
\end{abstract}

Keywords: floating vegetation, Drag coefficient, water velocity profile, water hyacinth.

\section{INTRODUCTION}

Aquatic vegetation in open-channel interrupts the flow through additional drag, and it causes a noticeable alteration of the turbulent flow compared to that in non-vegetated zones. The main influences of vegetation in open-channel are on horizontal and vertical distributions of mean and instantaneous velocity, on turbulence quantities and Reynolds stresses, and on transport of sediments and solutes. Vegetation influences flow patterns depending on stem density, frontal area, pattern of stem placement, depth of submergence and flexibility of the stem $[1,2,3,4,5,6,7,8,9,10,11,12,13,14,15,16]$.

Floating aquatic vegetation can be divided into two groups, rooted vegetation with floating leaves (pondweeds, water lilies and American lotus) and free-floating leaves with developed or underdeveloped roots (Water hyacinth, common bladderworts, and duckweeds) [17].

Water hyacinth spread widely in all rivers and water bodies and its ability to adjust and reproduce causes many problems in waterways with related to both hydraulic and water quality issues [18,19].

The presence of such rough covers (ice jam, floating vegetation and floating debris) changes the flow structure and velocity distribution [20,21]. Received:15 October, 2020, Accepted:14 February, 2021
Mohamed et al. [22] carried out study to investigate the impact of water hyacinth on flow behavior in open channels in a laboratory flume. Results show that in the presence of water hyacinth water surface profile rises before vegetation zone then goes down until reaches to normal water surface. Results also show that water surface profile influenced by vegetation density; vegetation root depth; vegetation zone length and bed roughness. Also the effect of vegetation parameters (density, root depth, zone length) on heading up, discharge and equivalent roughness coefficient was investigated and it is found that these plants parameters have a great effect on each of them. Multiple linear regression equations based on the dimensional analysis method were deduced to calculate heading up, discharge and equivalent roughness coefficient.

In the case of non-vegetated gravel bed river with turbulent flow conditions, the velocity vertical profile is often assumed to be logarithmically distributed $[23,24,25,26]$.

Tsujimoto et al. [27, 28, 29] have conducted several experimental and numerical studies using a modified version of the high Reynolds number $\mathrm{k}-\varepsilon$ model, with drag-related source terms that account for the presence of vegetation, to examine the impact of simulated vegetation on the velocity and turbulence fields in simple and compound channels they found 
a good agreement between the experimental observations and numerical predictions.

LAU [30] investigated velocity distributions for channel flows with floating covers using the $\mathrm{k}-\varepsilon$ turbulence model. The results indicated that the computed velocity distributions show that the velocity profiles are logarithmic only for about $60 \%$ of the layer thickness. For the $40 \%$ of the flow near the location of maximum velocity, the velocities are less than those given by the logarithmic distribution. They also found that the distance to the point of maximum velocity increases as the difference in the roughness of the boundaries increases.

Wilson et al. [13] investigated open channel flow through different forms of submerged flexible vegetation. They found that the additional drag exerted by plants reduces the mean flow velocity within the vegetated regions relative to un-vegetated ones.

Urantinon et al. [31] investigated the effect of water hyacinth on flow behavior in open channels, they used water hyacinth with three different root depths and three different densities, they found that water hyacinth floating on the water surface behaved like a solid wall since the velocity vertical profiles, with different amounts of water hyacinth, were similar to the theoretical velocity distribution in a closed conduit with a zero velocity in the root zone. This was due to the flow resistance at the water surface caused by the plants. The results also indicated that a denser and longer root depth of water hyacinth caused greater flow resistance and slow down the flow velocity.

Han et al. [32] modeled streamwise velocity of vegetation covered flow. They found that the vegetation covered flow structure is affected by the roughness characteristics of the channel bed and vegetation boundaries. So the vertical distribution of velocity is asymmetric regarding the plane of the maximum velocity because of the difference in roughness of the two boundaries.

Li and Shen [6] used a wake superposition model and the measured data by Petryk [33] to predict a drag coefficient. They studied numerically the effects of vegetation spacing and pattern on the drag coefficient. They found that the drag coefficient decreased slightly with the increases in the vegetation spacing.

Klaassen et al. [34] measured the hydraulic data in open channel flows with model vegetation of fruit trees, and they computed the drag coefficient using the Chezy formula. They obtained a higher value for the drag coefficient than the value obtained by $\mathrm{Li}$ and Shen [6]. They stated that the higher value of drag coefficient might be caused by the higher turbulence intensity in the fruit tree experiments.

Dunn [35] carried out some laboratory experiments for vegetated open channel flows. He found that the drag coefficient for rigid vegetation was not constant in the vertical direction, but reached a maximum at a distance approximately one third of the vegetation height above the bed.
Liu and Zen [36] investigated the drag coefficient for rigid vegetation in subcritical open channel. Based on dimensional analysis, they found that the influence factors on $\mathrm{C}_{\mathrm{D}}$ include hydraulic parameters such as Reynolds number, Froude number; and vegetation characteristics such as relative submergence of vegetation, and vegetation density. They concluded that the variation of $C_{D}$ with vegetation density is different.

The aim of this study is to investigate the impact of water hyacinth, as floating vegetation, on vertical velocity profile and vegetation drag coefficient in open channel. To achieve this aim experiments program was carried out in a rectangular, circulating water flume located in the Irrigation and Hydraulic Laboratory of Civil Engineering Department, Faculty of Engineering, Assuit University, Egypt, using water hyacinth which was harvested from natural streams.

Four different vegetation densities, three different vegetation root depths and three different vegetation zone lengths were used with smooth and rough channel bed. The case without water hyacinth was considered as comparative case.

\section{METHODS AND MATERIALS \\ 2.1 Theoretical Derivation}

Using the method of dimensional analysis and multiple linear regressions with the variables representing all the parameters involved in this study to investigate equations used in calculating vegetation drag coefficient in open channel due to the presence of water hyacinth.

The general functional relationship for these variables is given in the following form:

$F_{D}=\emptyset\left(\lambda_{v}, L_{v}, K_{v}, K_{b}, Y_{o}, U, \rho, g, \mu\right)$

Where $F_{D}$ is drag force, $\lambda_{v}$ is vegetation density, $L_{v}$ is vegetation zone length, $\mathrm{K}_{\mathrm{v}}$ is vegetation root depth, $\mathrm{K}_{\mathrm{b}}$ is bed roughness and defined by bed soilparticle size at which $90 \%$ is passing, $\mathrm{Y}_{\mathrm{o}}$ is water depth before vegetation zone, $U$ is flow velocity, $\rho$ is flow density, $g$ is gravity of acceleration, and $\mu$ kinematic viscosity.

Applying the Buckingham's " $\pi$ " theorem, the following non-dimensional form is obtained:

$\frac{F_{D}}{\rho Y_{O}^{2} U^{2}}=\emptyset\left(\lambda_{v} * Y_{O}^{2}, \frac{K_{V}}{Y_{O}}, \frac{L_{V}}{Y_{O}}, \frac{K_{b}}{Y_{O}}, \frac{U}{\sqrt{g Y_{O}}}, \frac{\rho U Y_{O}}{\mu}\right)$

Where the term $\frac{U}{\sqrt{\mathrm{g}} \mathrm{Y}_{\mathrm{o}}}$ is the Froude number $\mathrm{F}_{\mathrm{e}}$ and the term $\frac{\rho U Y_{0}}{\mu}$ is the Reynolds number $R_{e}$ Eqn. 2 was used in analysis correlation between vegetation variables (density, root depth and zone length) and vegetation drag force.

\subsection{Experimental work}

The experiments program were carried out in a rectangular, circulating water flume of dimension, 
$10 \mathrm{~m}$ long, $0.3 \mathrm{~m}$ wide and $0.3 \mathrm{~m}$ deep, which is located in the Irrigation and Hydraulic Laboratory of Civil Engineering Department, Faculty of Engineering, Assuit University, Egypt. The covered middle reach of the flume by water hyacinth collected from natural streams and the study variables are shown in figure (1).

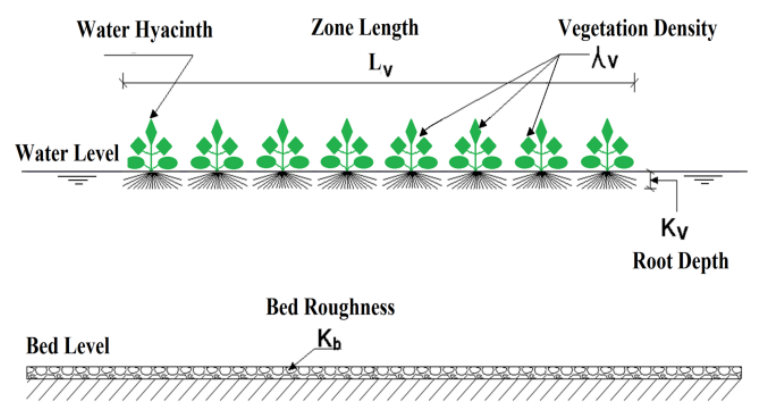

Figure (1): Definition sketch of water Hyacinth and the study variables

The laboratory flume with the circulated water closed system are shown in figure (2). The water depth was measured by a point gauge and the vertical velocity profiles were measured by Pitot tube. Measurements was taken every 0.1 water depth starting from bottom of the flume at vegetation length reach with different densities and root depths for smooth and rough channel bed. To study the effect of density, depth and length of vegetation in addition the effect of bed roughness on vertical velocity profile and drag force, four vegetation densities $\left(\lambda_{v}=30,60,90,120\right.$ pieces $\left./ \mathrm{m}^{2}\right)$, three vegetation root depths $\left(\mathrm{K}_{\mathrm{v}}=1,3,5 \mathrm{~cm}\right)$, three vegetation lengths $\left(L_{\mathrm{v}}=1,2,3 \mathrm{~m}\right)$ and four discharges $(10,12$, and $14,16 \mathrm{~L} / \mathrm{s})$ with smooth and rough channel bed are used as experiments variables.

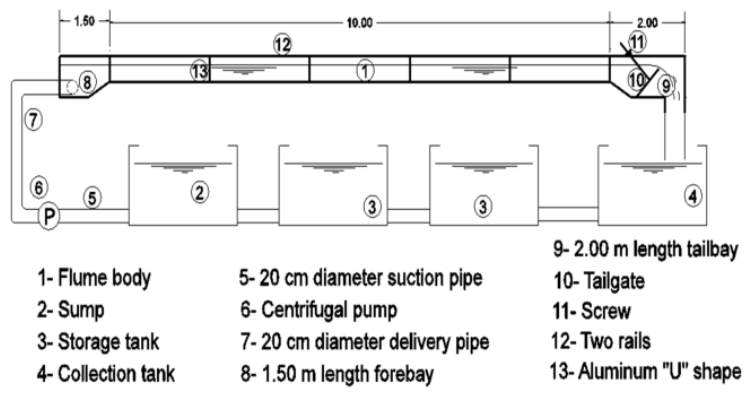

Figure (2). Schematic sketch of the experimental flume.

\section{RESULTS AND DISCUSSION}

The results of experiments were analyzed and discussed. The influences of density, root depth and infected length of vegetation in addition to the influence of bed roughness on velocity vertical profile and vegetation drag force were investigated.

\subsection{Vertical velocity profile}

\subsubsection{Vertical velocity profile of flow without vegetation}

The vertical velocity profile for free water surface (without water hyacinth) is shown in Figure (3), its value equals zero at the bed of channel due to bed roughness and increase in the vertical direction until reach its maximum value at the free water surface for both smooth and rough bed. So the velocity vertical profile was similar to the theoretical logarithmic distribution in an open channel.

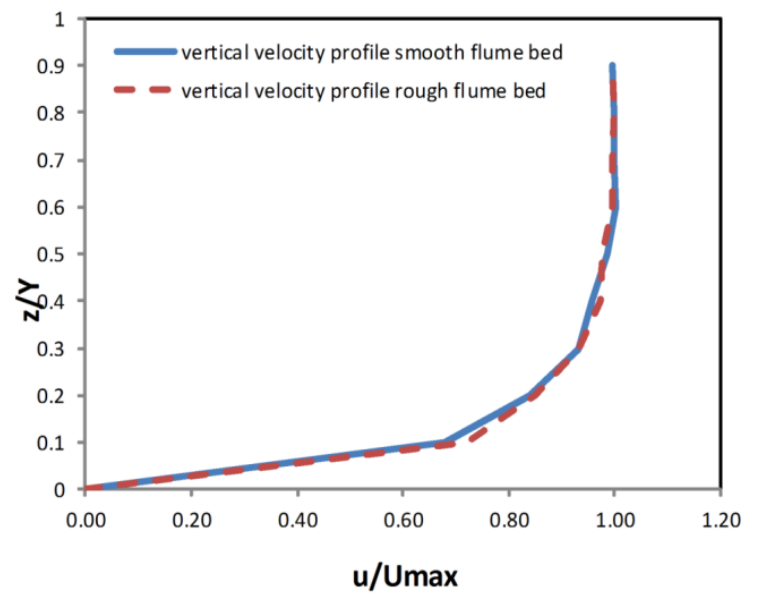

Figure (3): dimensionless vertical velocity profile for both smooth and rough flume bed without water hyacinth

\subsubsection{Vertical velocity profile of flow with vegetation}

The dimensionless velocity vertical profile for free water surface (without water hyacinth) and for presence of water hyacinth with different root depths and constant vegetation density in both smooth and rough channel beds are shown in Figures 4 and 5. It is clear these figures that, for both smooth and rough channel beds, changing the water hyacinth density and root depth alters velocity vertical profile of free surface case which similar to theoretical logarithmic distribution to a velocity vertical profile close to that of close conduit water flow where the velocity at the surface does not equal zero due to spaces between vegetation roots and flexibility of these roots and its value depends on the vegetation root depth. 
Vol. 41, No.2. July 2022

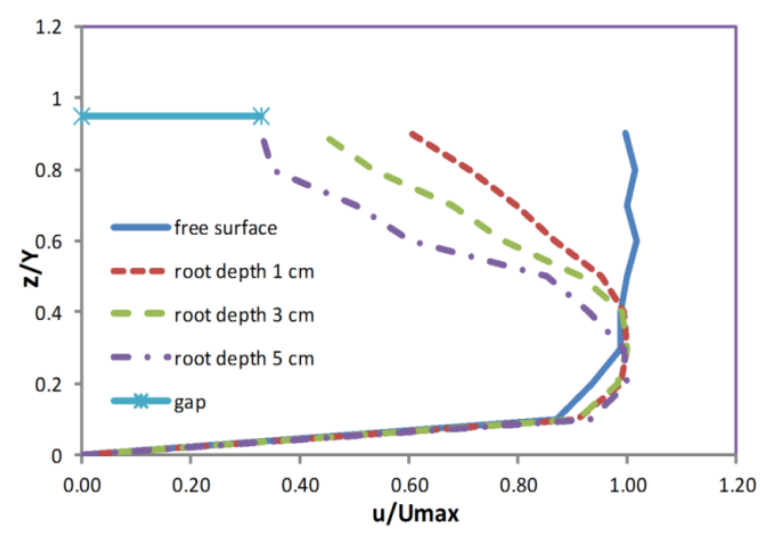

Figure (4) dimensionless vertical velocity profile for different vegetation root depth and constant density in smooth flume bed.

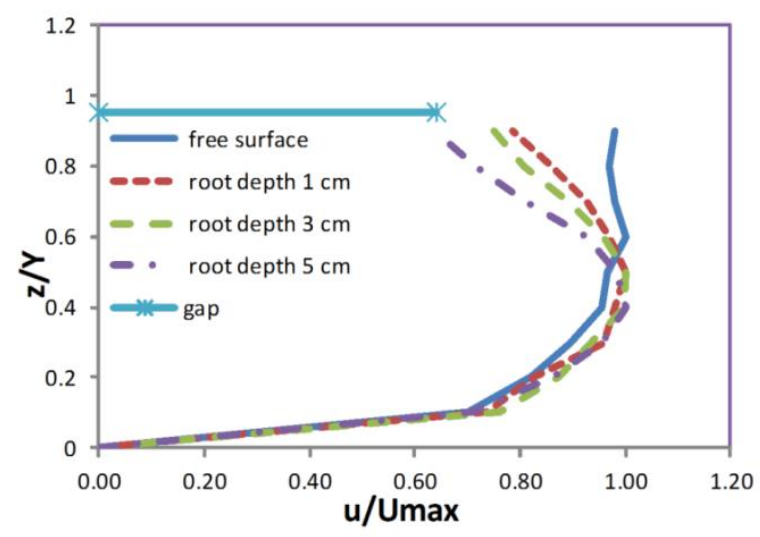

Figure (5). dimensionless vertical velocity profile for different vegetation root depth and constant density in rough flume bed.

\subsection{Effect of vegetation characteristic on}

\section{the location of maximum velocity}

Vertical velocity distribution is asymmetric due to location of maximum velocity which related to roughness of the two boundaries [32].

In case of infected flume with water hyacinth, the upper part of flow is affected by vegetation resistance and the lower part of flow is affected by channel bed resistance. The maximum velocity is located between the vegetation cover and the channel bed and influenced by both roughness. So when there is equal roughness between vegetation cover and channel bed, the location of maximum velocity is in the middle between vegetation and channel bed. When the roughness of both vegetation and channel bed, or one of them changes, maximum velocity moves toward the smooth surface. In figure (6) values of dimensionless vegetation root depth $\mathrm{K}_{\mathrm{v}} / \mathrm{Y}_{\mathrm{o}}$ is plotted versus location of maximum velocity as dimensionless $Z_{\text {max }} / Y_{o}$, the figure shows that when $\mathrm{K}_{\mathrm{v}} / \mathrm{Y}_{\mathrm{o}}$ increases $Z_{\text {max }} / Y_{o}$ decreases and when the values of $Z_{\max } / Y_{o}$ is plotted against dimensionless vegetation density $\lambda_{v} * Y o^{2}$, as shown in figure (7), which illustrates that $\mathrm{Z}_{\max } / \mathrm{Y}_{\mathrm{o}}$ also decreases with increasing in $\lambda_{v} * Y o^{2}$. it is clear from figures (6) and (7) that the location of maximum flow velocity is affected by flume bed roughness since its position is near to the more smooth boundary for different values of vegetation density and root depth.

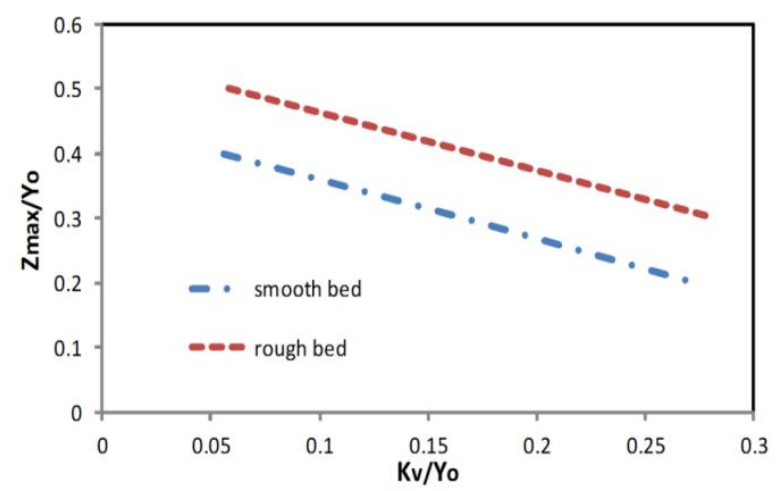

Figure (6) dimensionless location of maximum velocity for different dimensionless vegetation root depth in both smooth and rough flume bed.

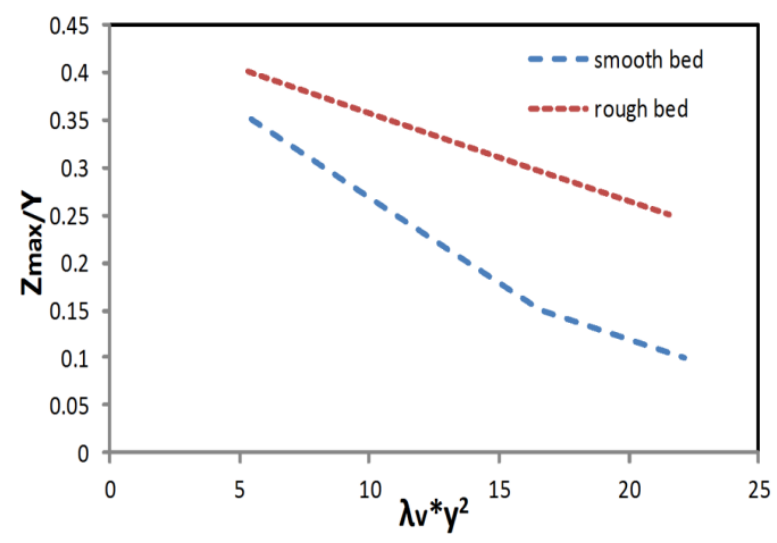

Figure (7) dimensionless location of maximum velocity for different dimensionless vegetation density in both smooth and rough flume bed.

\subsection{Effect of vegetation characteristic on}

\section{vegetation drag force}

Figure (8) Illustrates the relation between dimensionless vegetation drag force $\left(F_{D} / \rho Y o^{2} U^{2}\right)$ and dimensionless vegetation density for different vegetation zone lengths. The figure shows that the values of dimensionless vegetation drag force increases with the increases of both dimensionless vegetation density and the length of vegetation zone. 


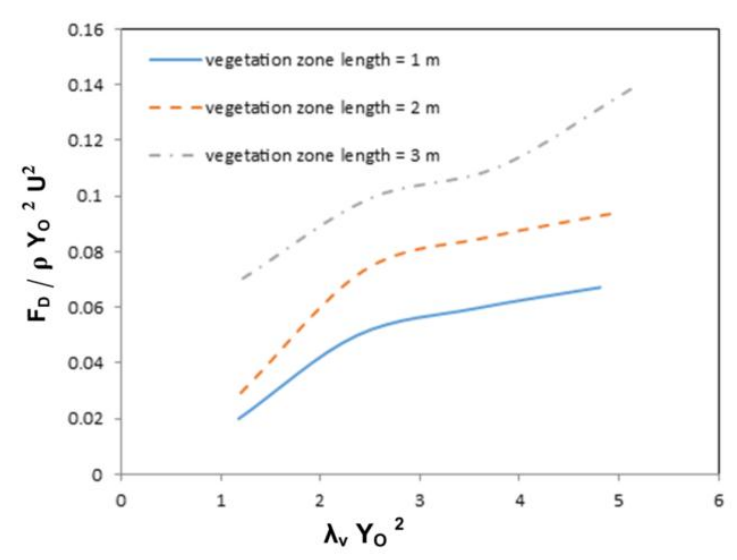

Figure (8) Variation of dimensionless vegetation drag force with dimensionless vegetation density for different vegetation zone lengths

Also the dimensionless vegetation drag force increases when both the dimensionless vegetation root depth $\left(K_{v} / Y_{o}\right)$ and the vegetation zone lengths increases as shown in Figure (9).

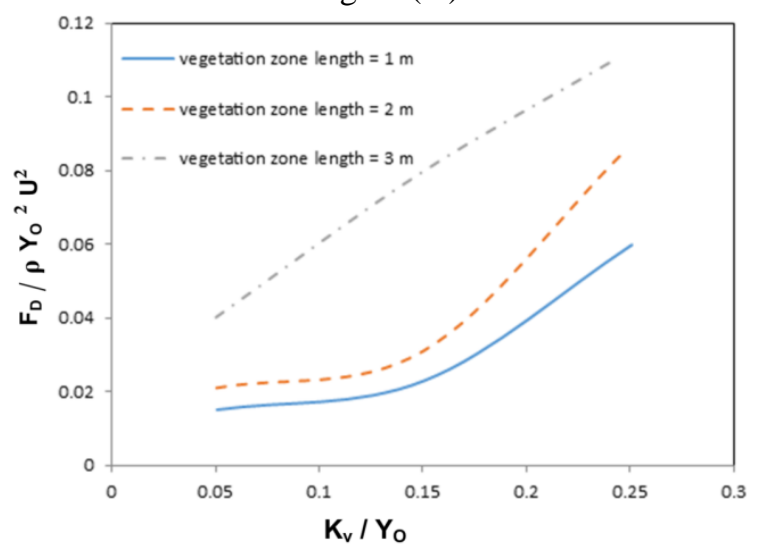

Figure (9) Variation of dimensionless vegetation drag force with the dimensionless vegetation root depth for different vegetation zone lengths.

Two equations for calculating vegetation drag force were derived using multiple linear regression analysis one for smooth flume bed with a coefficient of determination $R^{2}=0.82$ as follows.

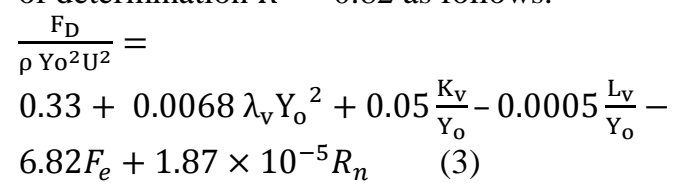

And the second for rough flume bed with a coefficient of determination $R^{2}=0.93$ as follows.

$\frac{\mathrm{F}_{\mathrm{D}}}{\rho \mathrm{Yo}^{2} \mathrm{U}^{2}}=$

$2.51+0.0067 \lambda_{\mathrm{V}} \mathrm{Y}_{\mathrm{o}}{ }^{2}+0.031 \frac{\mathrm{K}_{\mathrm{V}}}{\mathrm{Y}_{\mathrm{o}}}-0.0011 \frac{\mathrm{L}_{\mathrm{V}}}{\mathrm{Y}_{\mathrm{o}}}-$

$28.22 \frac{\mathrm{K}_{\mathrm{b}}}{\mathrm{Y}_{\mathrm{o}}}-3.76 F_{e}$

\section{CONCLUSIONS}

The presence of aquatic vegetation in irrigation canal retards water flow through additional drag force and causes many problems in waterways such as water flood and irrigation water shortage at the ends of irrigation channels. In this study, a series of laboratory experiments were conducted to investigate the impact of water hyacinth, as floating vegetation, on vertical velocity profile and vegetation drag coefficient in open channel. The main conclusions drawn from this study can be summarized as follows:

1. Water hyacinth density and root depth have a significant effect on vertical velocity profile where changing in water hyacinth density and its root depth alters vertical velocity profile of free surface which similar to that of close conduit water flow but the velocity at the surface does not equal zero due to spaces between vegetation roots and flexibility of these roots.

2. Water hyacinth density, its root depth and bed roughness change the position of maximum velocity where increase of vegetation density and vegetation root depth, moves maximum velocity down toward channel smooth bed, and when channel bed became rough, maximum velocity moves up toward channel surface.

3. The vegetation drag force increases as the vegetation density, vegetation root depth and vegetation zone length are increased.

4. Two equations were developed using dimensional analysis and multiple linear regression analysis for calculating vegetation drag force at both smooth and rough channel beds.

\section{REFERENCES}

[1] Bennett SJ, Pirim T and Barkdoll BD (2002) "Using simulated emergent vegetation to alter stream flow direction within a straight experimental channel." Geomorphology 44 115-126.

[2] Fathi Moghadam M and Kouwen (1997) "Nonrigid, non-submerged, vegetative roughness on floodplains." J. Hydr. Engr., 1231) 51-57.

[3] Freeman G E, Rahmeyer W H and Copeland R $R$ (2000) "Determination of resistance due to shrubs and woody vegetation." ERDC/CHL TR-00-25, U.S.ACE.

[4] Järvelä J (2002) " Flow resistance of flexible and stiff vegetation: a flume study with natural plants." J. Hydr. 269, 44-54.

[5] Järvelä J (2004) "Determination of flow resistance caused by non-submerged woody vegetation." Int. J. River Basin Mgmt. 2(1) 6170 . 
[6] Li R M and Shen H W (1973) "Effect of tall vegetation on flow and sediment" J. Hydr. Div. ASCE, 99(5): 793-814.

[7] Lopez F and Garcia M (1998) "Open channel flow through simulated vegetation: suspended sediment transport modeling" Water Res. Res. 34(9) 2341-2352.

[8] Lopez F and Garcia M H (2001) "Mean flow and turbulence structure of open-channel flow through non -emergent vegetation" J. Hydr. Eng. 127(5) 392-402.

[9] Nepf H M (1999). "Drag, turbulence , and diffusion in flow through emergent vegetation." Water Resources Research, 35 (2), 479 -489.

[10] Petryk S and Bosmajian G (1975) "Analysis of flow through vegetation." J. Hydraul. Div. ASCE 101(HY7) 871-884.

[11] Stone B M and Shen H T (2002) "Hydraulic resistance of flow in channels with cylindrical roughness." Journal of Hydraulic Engineering 128(5), 500-506.

[12] White B L and Nepf H M (2008) "A vortexbased model of velocity and shear stress in a partially vegetated shallow channel." Water Res. Research, 44(W01412) 15.

[13] Wilson C A M E, Stoesser T, Bates P D and Batemann Pinzen A (2003) "Open channel flow through different forms of submerged flexible vegetation." J. Hydr. Engr., 129(11), 847-853.

[14] Wilson C A M E, Yagci O, Rauch H P and Stoesser T (2006a) "Application of the drag force approach to model the flow-interaction of natural vegetation." Int. J. River Basin Mgmt. 4(2) $137-146$.

[15] Wilson C A M E, Yagci O, Rauch HP and Olsen N R B (2006b) "3D numerical modeling of a willow vegetated river/floodplain system." Journal of Hydrology, 327 13-21.

[16] Mohamed, H. I. (2010) "Flow Characteristics of Partially Vegetated Trapezoidal Channel Cross-Section." 14th Int. Water Techn. Conf. IWTC14, Cairo, Egypt, pp. 203-220.

[17] Folkard A M (2011) "Flow regimes in gaps within stands of flexible vegetation: Laboratory flume simulations." Environmental Fluid Mechanics 11(3) 289 - 306.

[18] Saknimit (1976) "Study of the Productivity of Water Hyacinth. M.Sc. Thesis. Chulalongkorn University Bangkok Thailand.
[19] Bocchiola D, Catalano F, Menduni G and Passoni G (2002) "An analytic numerical approach to the hydraulics of floating debris in river channels." Journal of Hydrology 269 65-78.

[20] Teal M J, Ettema R and Walker J F (1994) "Estimation of Mean Flow Velocity in Ice Covered Channels. Journal of Hydraulic Engineering 120(12) 1385-1400.

[21] Smith B T and Ettema R (1997) "Flow Resistance in Ice-Covered Alluvial Channels." Journal of Hydraulic Engineering 123(7), 592599.

[22] Mohamed, H. I, Abd-Elaal, A. M, Mahmoud, A. A. (2020) " Flow Characteristics of Open Channels with Floating Vegetation" Journal of Engineering sciences. Faculty of Eng. Assiut, Egypt, Vol. 48 No.2.

[23] Chow VT (1959) "Open- channel hydraulics" McGraw-Hill, New York.

[24] Ferro V (1999) "Friction factor for gravel-bed channel with high Boulder Concentration" Journal of Hydraulic Engineering 125 (7) 771 778.

[25] French R H (1994) "Open-channel hydraulics" McGraw-Hill, Singapore, 739 pages.

[26] Graf W H and Altinakar M S (1998) "Fluvial hydraulics: Flow and transport processes in channels of simple geometry" Wiley Chichester England 681 pages.

[27] Tsujimoto T, Kitamura T and Okada T (1991a) " Turbulent structure of flow over rigid vegetation covered bed in open -channel KHL Progressive Report 7, Hydr. Lab., Kanazaw a University, Japan.

[28] Tsujimoto T, Okada T, and Kitamura T (1991b) " Turbulent flow over flexible vegetation covered bed in open channels." KHL Progressive report 91 Hydr. Lab. Kanazaw a University, Kanazaw, Japan, 31 -39.

[29] Tsujimoto $\mathrm{T}$ (1992) "Spectral analysis of velocity and water-surface fluctuations appearing in an open channel with vegetated and non - vegetated regions in a cross-section." Proc. 6th IAHR Int. Symposium on Stochastic Hydraulics, Taipei, Taiwan, 361 -368.

[30] LAU Y L (1982) "Velocity distributions under floating covers " Canadian Journal of Civil Engineering 9(1) 76-83.

[31] Urantinon A and Pilailar S (2015) "Effect of water hyacinth on open channel water flow 
Vol. 41, No.2. July 2022

behavior: Laboratory scale." Kasetsart Journal Natural Science 49(6) 913-923.

[32] Han L, Zeng Y, Chen L, and Li M (2018) "Modeling streamwise velocity and boundary shear stress of vegetation-covered flow." Ecological Indicators, 92 , 379-387.

[33] Petryk S (1969) "Drag on cylinders in open channel flow" $\mathrm{PhD}$ thesis Colo. State Univ., Fort Collins.
[34] Klaassen G J and Zwaard J J (1974) "Roughness coefficients of vegetated floodplains." J. Hydr. Res. 12(1): 43-63.

[35] Dunn CJ (1996) "Experimental determination of drag coefficients in open channel with simulated vegetation." MSc Thesis, University of Illinois at Urban-Champaign, Urbana, IL.

[36] Liu X and Zen Y (2016) "Drag coefficient for rigid vegetation in subcritical open-channel flow." Environmental Fluid Mechanics, 154(5) 1124-1131.

$$
\text { تأثير نبات ورد النيل على المنحنى الرأسى لسرعة السريان وعلى معامل اعاقة السريان في قنوات الري }
$$

وجود الحشائش المائية في قنوات الري يؤخر تدفق المياه حيث يمثل قوة اعاقة اضافية للريان المياه. هدف البحث دراسة تأثير نبات ورد النيل على المنحنى الرأسى لسرعة السريان وعلى معامل اعاقة السريان في قنوات الري. ولتحقيق هذا الهدف تم تنفيذ برنامج عملى في قتاه معملية

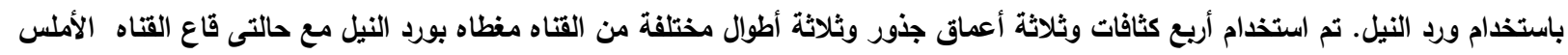

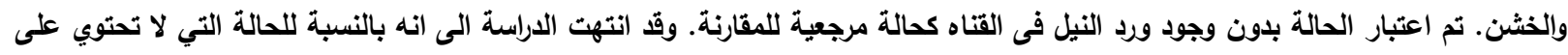
ورد النيل ، فإن المنحنى الرأسى لسرعة السريان يشبه التوزيع اللوغاريتمي النظري في القناة المفتوحة فى حين انه مع وجود ورد ودئ النيل أصبح المنحنى الرأسى لسرعة السريان قريب من توزيع السرعة النظري في المجارى المغلقة وأكنها لم تصل إلى الصفر عند سطح الماء. كما أن كثافة

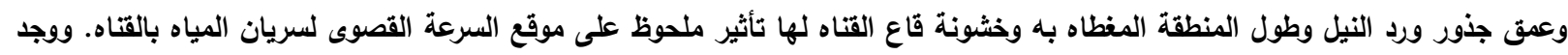

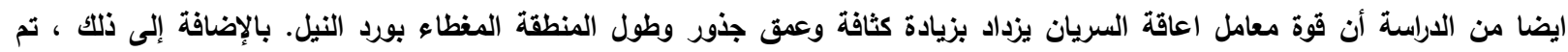
استتتاج معادلات باستخدام تحليل الانحدار الخطي المتعدد لحساب معامل الاعاقة لحالتى قاع القناه الأملس والخشن. 